\title{
The Metaphor of Craving in the Tanha Vagga of the Dhammapada Scripture (Semantic Study of Buddhist Texts)
}

\author{
Santi Paramita ${ }^{1 *}$, Hesti Sadtyadi ${ }^{2}$ \\ 1 Sekolah Tinggi Agama Buddha Negeri Raden Wijaya Wonogiri, Indonesia; e-mail: \\ santiparamita72@gmail.com \\ 2 Sekolah Tinggi Agama Buddha Negeri Raden Wijaya Wonogiri, Indonesia; e-mail: \\ 15hestisadtyadi@gmail.com \\ * Correspondence
}

Received: 2021-10-28; Accepted: 2021-12-12; Published: 2021-12-31

\begin{abstract}
The purpose of this study is to describe: (1) Haley's model of human perceptual space category used to create the metaphorical expression of craving in the Tanha Vagga verse of the Dhammapada scripture, (2) the distribution of Haley's category of human perceptual space that is most prominently used to create the metaphorical expression of craving in the Tanha Vagga verse of the Dhammapada scripture, (3) the state of the ecological system as seen in the metaphor of craving in the Tanha Vagga verse of the Dhammapada scripture based on the distribution of the use of Haley's category of the human perceptual space. This research is descriptive qualitative research, with the Content Analysis technique. The data source is the Tanha Vagga Dhammapada Scripture. The results showed: (1) in the Tanha Vagga scripture Dhammapada there are 31 metaphors of craving that can be categorized into the five spaces of human perception according to Haley's model, including the categories of being, energy, terrestrial, object and living. (2) Based on the results of the distribution of the use of Haley's model of human perceptual space, it was found that the living category was the most prominent type of craving metaphor category with a percentage of $35.4 \%$, (3) the percentage distribution results reflected the unbalanced state of the ecological system in the Tanha Vagga verses of Dhammapada. The metaphorical expression of craving in the Tanha Vagga of the Dhammapada scriptures is packaged in a metaphorical form which means controlling lust ( $\tanh \bar{a}=P a l i)$ which causes dukkha (suffering) and the cycle of rebirth (samssāra). Buddhism seeks to eliminate tanhha to eliminate dukkha.
\end{abstract}

Keywords: Dhammapada; metaphors; Haley's model of human perceptual space category; Tanha Vagga.

\begin{abstract}
Abstrak: Tujuan dari penelitian ini adalah untuk mendeskripsikan: (1) model kategori ruang persepsi manusia menurut Haley yang digunakan untuk menciptakan ekspresi metaforis dari hawa nafsu/hasrat dalam syair Tanha Vagga dari kitab suci Dhammapada; (2) distribusi kategori ruang persepsi manusia menurut Haley yang paling menonjol digunakan untuk menciptakan ekspresi metaforis dari hawa nafsu dalam syair Tanha Vagga dari kitab Dhammapada; (3) keadaan sistem ekologi seperti yang terlihat dalam metafora hawa nafsu dalam syair Tanha Vagga dari kitab Dhammapada berdasarkan distribusi penggunaan kategori Haley tentang ruang persepsi manusia. Penelitian ini merupakan penelitian deskriptif kualitatif, dengan teknik Analisis Isi. Sumber datanya adalah syair Tanha Vagga dalam Kitab Suci Dhammapada. Hasil penelitian menunjukkan: (1) dalam syair Tanha Vagga dalam Kitab Suci Dhammapada terdapat 31 metafora tentang hawa nafsu/ hasrat yang dapat dikategorikan ke dalam lima ruang persepsi manusia menurut model Haley, meliputi kategori makhluk, energi, bumi, objek dan kehidupan. (2) Berdasarkan hasil sebaran penggunaan ruang persepsi manusia model Haley ditemukan bahwa kategori hidup merupakan kategori metafora yang paling menonjol dengan persentase $35,4 \%$, (3) distribusi persentase hasilnya mencerminkan keadaan sistem ekologi yang tidak seimbang dalam syair-syair Tanha Vagga dalam Kitab suci Dhammapada. Ungkapan metafora hawa nafsu/keinginan dalam syair Tanha Vagga dari kitab
\end{abstract}


Dhammapada dikemas dalam bentuk metafora yang berarti mengendalikan nafsu ( $\tanh \bar{a}=$ Pali) yang menyebabkan dukkha (penderitaan) dan siklus kelahiran kembali (saṃsāra). Buddhisme berusaha menghilangkan tanh $\bar{a}$ untuk menghilangkan dukkha.

Kata Kunci: Dhammapada; metaforis; model kategori ruang persepsi manusia menurut Haley; Tanha Vagga.

\section{Introduction}

Most human activities are inseparable from language activities. This is in line with the function of language itself, which is a human tool to convey ideas, feelings, or desires, as well as a means of interactions with the wider community. Kridalaksana $(1993 ; 315)$ states that language is a soundsymbol system used by a member of society to interact, to identify one's self, and to cooperate.

Metaphors are more commonly used in language. However, the use of metaphor is also very prevalent in thought and action (Ganiwati, 2020). Metaphor is a part of figurative language styles or figure of speech. (Keraf, 2010) divides language based on direct and indirect meanings, i.e., whether the meanings used are still within the scope of denotative meanings or have experienced deviations. The indirect figure of speech style is divided into two groups, namely rhetorical language style and analogical language style. Rhetorical language is divided into several parts, including alliteration, assonance, anastrophe, apostrof, asyndeton, polysyndeton, hyperbole, and paradox. Analogous or figurative language is divided into metaphor, simile, allegory, personification, eponym allusion, synecdoche, and hypalase (Keraf, 2010).

The discussion of metaphor is also widely associated with the study of the language of poetry and other literary works. A metaphor can occur due to a change in meaning in two objects (Oktavia, 2019). This transfer is based on the similarity of perception of meaning at the semantic level (Keraf, 2010). Understanding the metaphorical meaning can be done by analysing the components of meaning in words, phrases, or sentences. Metaphors are related to the use of language in conveying meaning. Two things are compared in a metaphor called the domain which consists of the source, which is a domain that supports the expression of literal meaning, and the target which is the result of verbalising the process of the meaning concept of the source domain to the target domain about something (Croft \& Alan Cruse, 2004).

Understanding metaphors are generally seen from two perspectives, through the theory of linguistic metaphors and conceptual metaphors. Linguistic metaphors see metaphors from three elements, namely vehicle (topic), tenor (image), and ground (equation). Slightly different from the previous theory, conceptual metaphors suggest that metaphor has two conceptual domains, namely the target domain and the source domain (Pebriawati, 2016). Even so, the metaphors in those two concepts have three basic components, namely vehicle (topic), tenor (image), and ground (equation). If simplified, conceptual metaphor is the process of transferring a known concept to another unfamiliar concept, so that the foreign concept can be more easily understood, while linguistic metaphors are linguistic expressions obtained through conceptual metaphors. This research uses linguistic metaphors to analyse the metaphors found in the poems, or more precisely the tanha metaphors in the Tanha Vagga verses in the Dhammapada scriptures.

In poetry, there is a mixture of the real world and the figurative world (Wahab, 2013). Thus poetry is rich in metaphor. In addition, in poetry, there are also metaphorical statements used by the poet when he creates poetry or rhymes (Suriyadi, 2013). The metaphorical statement is a symptom of language in poetry which is realised in the form of a figurative symbol (signifier) and the intended meaning (signified)(Nabila \& Hasanah, 2021). Furthermore, Robert and Marvin (Wahab, 2013) state that "poetry is the way of saying one thing and meaning of another." Thus, poetry has the same function as metaphor, which is to say one thing but has another purpose. However, poetry is not a metaphor and vice versa. The similarity between poetry and metaphor is because the poet has the right of poetica licensia, which is a right to use their imagination of a free world to equip this world with whatever one 
chooses, both with objects taken from the real world and with objects that exist in the poet's imagination.

In the verses of Dhammapada, most of them feature figurative symbols and language. These figurative symbols or language were aimed to direct or convey ideas, teachings, moral criticism, feelings, and so on. Similar to the above explanations on poetry and songs, scriptures verses also contain a mixture of the real world and the figurative world, as seen in the verses of the Dhammapada scriptures which are also rich in metaphorical expressions. Based on this statement, it is very interesting to analyse further, especially the study of the metaphor of the Dhammapada poetry.

The poems described above are not much different from the verses for Dhamma sermons in the Dhammapada scriptures. The verses delivered are full of figurative language. This is because of the typical phenomenon of the use of language in the poems arranged in lyrical (full of feeling) stanzas. Dhammapada verses are a form of inner expression and ideas of Gautama Buddha related to what he saw and experienced. In addition, lyrics are defined as literary works (poems) that contain an outpouring of personal feelings (Departemen Pendidikan Nasional, 2008). Thus, lyrics can be stated to have similarities with poetry and have special features in their language.

Dhammapada is the title or the name given to a section of the Buddhist scriptures. This book is an anthology containing various teaching aspects of Buddha, which shows various points of view that can be used to get a glimpse of the essence of the teachings. Based on the initial analysis of the Tanha Vagga verses in the Dhammapada scriptures, there was found many figurative symbols of metaphorical expressions that can be classified into nine categories of Haley's model of ecological systems (human perceptual space). The following is one of the data for the tanha metaphor in the Tanha Vagga poem.

\section{Manujassa pamattacarino \\ tanha vaddhati maluva viya \\ so palavati huhuram \\ phalam iccham va vanasami vanaro \\ Source: Widjaya (2013)}

Translation: In a man who is unmindful craving grows like a creeper. He runs from birth to birth, like a monkey seeking fruits in the forest

Craving means an impulse to do bad things (Departemen Pendidikan Nasional, 2008). Gautama Buddha described craving as a creeper that has the property of being able to grow. Judging from the criteria for the figurative symbol of creeping plants in this metaphorical expression, it is in line with the criteria for the living category, i.e. a metaphor whose figurative symbol refers to the life of flora and all predications that grow like plants such as wood, flowers, grass and so on.

The creation of a metaphorical expression with the figurative symbol of a creeping plant describes a poet's interaction with his environment. The figurative symbol has criteria that match the living category in Haley's hierarchy of perception space. Thus, the creation of a metaphor cannot be separated from the poet's interaction with his environment. This is in line with the statement which suggests that in thinking and creating metaphors, humans cannot escape from their environment, because they always interact with it (Wahab, 2013). The study of the interaction between humans and their environment, both animate and inanimate creatures is called an ecological system.

The verses of the Dhammapada scriptures will be used as objects of research and will be analysed based on the figurative symbols used in the metaphorical expressions. Next, the data is classified into Haley's model of the human space perception category, and the frequency distribution of its use is identified. This is done to find out the most prominent metaphor category for Haley's model of human space perception and the corresponding state of the author's ecological system. This shall cover three things: (1) the problem being studied; (2) the urgency of raising the issue being studied; and (3) the way the author discusses the problem.

In this study, the formulation of the problem is: What are, based on Haley's model, the categories of human perceptual space used to create the metaphorical expression of craving in the Tanha Vagga verse of the Dhammapada scripture? What is the distribution of the categories of human perceptual space according to Haley's model which is most prominently used to create the metaphorical expression of craving in the Tanha Vagga verses of the Dhammapada scripture? How is the state of the 
ecological system seen in the metaphor for craving in the Tanha Vagga verses of the Dhammapada based on the distribution of the use of Haley's categories of human perceptual space?

This research is a qualitative descriptive study (Subandi, 2011)(Nugrahani, 2014). Considering that this research is qualitative, the analysis focuses on indicating the meaning, description, clarification, and placement of data in their respective contexts and often describes them in the form of words rather than numbers (Mahsun, 2011). A study which is done by describing the categories of human perceptual space in Haley's model, as conveyed by (Wahab, 2013), that the ecological system of human perception space consists of nine categories of hierarchical human perception spaces that are ordered. The hierarchy of human perception space includes being, cosmos, energy, substance, terrestrial, object, living, and human (Yuniseffendri, 2014). The categories are taken based on the concept of a hierarchy of human perceptual spaces, which are used to make metaphorical expressions in the Tanha Vagga verse of the Dhammapada, describe the categories of human perceptual spaces in Haley's most prominent model, and describe the state of the ecological system in the Tanha Vagga of the Dhammapada, included in the study. qualitative descriptive.

The data used in this study is the text of the Tanha Vagga verses contained in the Dhammapada Holy Scripture, which consists of 26 verses. The primary data source used in this research is the wordper-word Pali-Indonesian translation of the Dhammapada Scriptures along with the backstory translated by Hendra Widjaya, in 2013, published by the Ehipassiko Foundation.

This study uses data analysis techniques with content analysis (Kroppendorf, 1980),(Hendriyani, 2017),(Assarroudi, Heshmati Nabavi, Armat, Ebadi, \& Vaismoradi, 2018),(Monggilo, 2020). The procedure for analysing the metaphor of craving in the Tanha Vagga verses, through Semantic Content Analysis, is understanding the text by classifying signs according to their meanings.

\section{Metaphorical Expression of Tanha Vagga in Dhammapada}

The data of this research are in the form of phrases, clauses, and sentences containing metaphorical expressions in the collection of Tanha Vagga verses from the Dhammapada scriptures. Based on the research that has been done, 26 poems were obtained.

The amount of data is found by the researcher. The amount of data still can change because the data validity has not been confirmed by researchers. Therefore, this study uses the triangulation technique of investigators or other researchers to test the validity of the data. In this effort, the researcher triangulated the data with two lecturers who are competent in the fields related to Indonesian Language and Literature Education.

Based on the results of the analysis by the two triangulators, among the initial data of 26 verses, there were 31 quotations of metaphorical expressions with the criteria of research data. Therefore, the research data that will be analysed further in this study amounts to 31 metaphorical expressions of craving in the form of phrases, clauses, and sentences contained in the Tanha Vagga verses of the Dhammapada scripture.

The quoted data that had been declared valid after going through a series of validation tests where the results are approved by the triangulators were then given a numbering code as seen in the data table. The data that do not meet the criteria and are declared invalid are the data in the table that are not given numbering codes, for example, verses $8,15,20$, and 21 . These data are declared invalid because they do not contain words or metaphorical expressions of craving. In general, the invalid data are only in the form of expressions that have a literal meaning or use metaphorical expressions, but these expressions do not refer to the meaning of craving, for example, the number 15 verse in the table.

Having gone to the shore across from life,

with a mind completely liberated,

you no longer experience birth and aging.

The "shore across from life" is also a form of metaphorical expression in the form of a phrase, but the metaphorical expression "shore across from life" in that verse does not refer to craving. 


\section{Haley's Model of Human Perceptual Space of the Metaphor of Craving in Tanha Vagga}

In this section, the stages of data analysis using Semantic Content Analysis are presented by going through the procedure of understanding the text by classifying the signs according to their meaning (Kroppendorf, 1980). The analysis includes several stages. The first stage is interpreting metaphorical expressions by looking for criteria for figurative symbols based on the Great Indonesian Dictionary and the Dhammapada Holy Book which contains the Background Story of the emergence of these poems. The second stage is the categorisation stage, where the researcher classified the data by considering the suitability of the figurative symbol criteria used to create the metaphor into nine categories of Haley's model of human perceptual space. The nine categories are 1) Being, 2) Cosmos, 3) Energy, 4) Substance, 5) Terrestrial, 6) Object, 7) Living, 8) Animate, and 9) Human.

\section{Interpretation and Categorisation Stage}

Being

The category of being is said to have the concept of abstract human experience. In this category, four metaphorical expressions are found in the collection of Tanha Vagga verses, which are: Mara, sensual pleasures, attachment, and greed. The following is an analysis of data from one category of being that is used to create the metaphor of craving in Tanha Vagga.

"...don't let mara destroys you again and again" (TV 337.b.). The word mara in the data (TV 337.b.) is an abstract concept that cannot be directly felt by the human senses but is only experienced by faith and belief. Mara means disaster or danger (Departemen Pendidikan Nasional, 2008). Therefore, the symbol of mara can be regarded as an abstract and true concept of human experience. Its existence can only be lived by faith. In the metaphorical expression of data (TV 337.b.) mara is described as a human being who can destroy someone's life over and over again.

This piece of poetry is based on the story of Bhikkhu Kappila's life journey. He was a very welleducated and famous Bhikkhu. He taught the Dhamma to many people, but unfortunately, Bhikkhu Kappila had a very arrogant nature and had a habit of belittling other Bhikkhu. If someone called him out, he would get very angry. This made everyone avoid him, which only made him angrier. He also began to hate and berate the other monks and the Dhamma. Due to this pride and hatred, he was forced to suffer in the realm of misery for a long time. Arrogance and hatred are part of the nature of tanha, which can ruin or destroy a person's life.

Judging from the criteria of the figurative symbol of mara in the metaphorical expression (TV 337.b.) it has conformity with the criteria of being category. The next analysis of the data that falls into the category of being in the Tanha Vagga of the Dhammapada scriptures is as follows.

Fields damaged by weeds, (TV 356.a.)

mankind is corrupted by greed (TV 356.b.).

Therefore, what was given to them

who is not greedy will bear great fruit.

Greedy means wanting to get a lot for yourself, while greed means the desire to always get as much (wealth and so on) as possible (KBBI, 2008). This meaning corresponds to the background story of the verse told by Gautama Buddha. It was told that Lord Ankura felt that during his life in this world he had given so much food to others, while Lord Indaka had only given a small amount of food to Bhikkhu Anurudha. However, they were both born in the same place, and Lord Ankura could not accept it. In the end, Gautama Buddha explained that the quality of the gift is more important than the amount of the gift (Widjaya, 2013 p.842). From this description, it can be concluded that the mind of Lord Ankura was filled with the desire to get as much reward as possible (greed) for what he had done.

Greed can be called an abstract and true concept of human experience. Its existence can only be experienced through faith. In the metaphorical expression of the data (356.b.), greed is symbolised by a human being that can destroy other people's lives. Judging from the criteria of the figurative symbol of greed in the metaphorical expression (356.b.), it is following the criteria of the category of being. This 
shows that there is a form of human interaction with beings that includes the experience of an abstract thing that is true. Thus, the creation of Gautama Buddha's metaphorical expression with the figurative symbol of greed can be classified in the category of beings in Haley's hierarchy of human perceptual space.

\section{Cosmos}

A cosmic category is a cosmic object that has a long distance and occupies space as part of the horizon but its existence can still be observed by the five human senses. Concrete examples include the sun, earth, moon, and others, which, not only exist but also occupy space in the universe. In this collection of Tanha Vagga poems, there is no data of metaphorical perception space that is categorised as cosmos.

\section{Energy}

The category of energy has predictive of not only existing and occupying space but also having a motion behavior. The following is an analysis of the data that uses metaphorical expressions that represent this energy category.

The misguided man in whom the thirty-six currents of craving

strongly rush toward pleasurable objects,

is swept away by the flood

of his passionate thoughts. (TV 339).

The essence of the phrase thirty-six currents comes from the words thirty-six and current. Thirtysix itself refers to the number, while the word current means the movement of flowing water (KBBI, 2008: 88). This verse has the same background story as data (TV 338) which is about a woman who was reborn multiple times in the form of an animal. But after having had the opportunity to listen to the Dhamma, she was able to realise her mistake and began to meditate on the object of the repulsive nature of the body, so she was reborn as a Brahma (Widjaya, 2013 p.802)). From this background story, it can be concluded that the lower desires (cravings) in the human mind are like currents (streams of water) that will drag one to lead a low life, being reborn as an animal over and over again.

The same analysis was carried out in the next verse, which also uses metaphorical expressions similar to the data (TV 339). The quoted verse is as follows.

Current flows everywhere, (TV 340.a.)

after bursting, the creeper sprouts and grows. (TV 340.b.)

Seeing that the creeper has sprung up,

cut off its root with wisdom.

Judging from the criteria of the figurative symbol of current in the metaphorical expression (TV 340.a.), it has the same meaning as the symbol of the thirty-six currents in the metaphorical expression (TV 339), which is in accordance with the criteria of the energy category. This shows that there is a form of human interaction with energy with concrete examples including light, fire, and the like, with predictions of not only, exist and occupy, but also having a motion behavior. Thus, the creation of Gautama Buddha's metaphorical expressions on data (TV 339) and data (TV 340) with the symbol of thirty-six currents and symbol of current can be classified in the energy category in Haley's model of human perceptual space.

Substantial/Substance

The substantial category has a perceptual space and can be felt by the five human senses because it exists in the human environment, moves, and is inert. Similar to the cosmos category, there are also no words nor phrases that are used as metaphorical expressions of craving in the Tanha Vagga Dhammapada scriptures that can be classified in the substantial category in Haley's model of human perception. 


\section{Terrestrial}

The terrestrial category includes any expanse that is bound by the earth. This category is found in only one data, but its use is repeated several times in the Tanha Vagga verses.

The following is the result of data analysis on terrestrial category expressions used to create the metaphor of craving in Tanha Vagga.

He who is free from the thickets and determined to go to the forest. (TV 344.a.)

Freed from the forest, but ran back into the forest. (TV 344.b.)

Come and see the man

Freed, but runs back again into the forest.

The word forest according to the Indonesian dictionary means land overgrown with trees or plants that grow on very large land (which is usually in mountainous areas)(KBBI, 2008). The expression of this verse is based on the story of a person who at first had become a monk, but because he saw gold, he developed a desire to have it. Because of this desire, he then left the Sangha (association of monks) to become an ordinary person again. In short, due to mingling with the wrong crowd, he eventually became a thief, so he was caught and was about to be put to death. At the end of the story, the person is helped by Gautama Buddha and finally returns to living the life of a monk (Widjaya, 2013 p. 814).

In the metaphorical expression in the data (TV 344.b.) the figurative symbol of the forest is a symbolisation of craving or desire. Life as a samana or monk comes in the form of life one chooses to keep away from the worldly life which is filled with temptations and defilements. The human mind (such as the mind of the Bhikkhu who has left the Sangha) who has been overcome with craving and desire for material possessions (gold) is described as returning to the forest. So the forest acts as a figurative symbol (signifier), while the intended meaning (signified) of the word is craving.

Judging from the criteria of figurative forest symbols in metaphorical expressions (TV 344) it has conformity with the criteria for the terrestrial category. This shows that there is a form of human interaction with terrestrial, which includes expanses bound by the earth, oceans, rivers, mountains, deserts, and the like. Thus, the creation of a metaphorical expression of craving for data (TV 344.b.) with a forest metaphor can be classified in the terrestrial category in Haley's model of human perception.

Object

The category of objects in the semantic field of human perceptual space refers to anything related to objects. Expression of object categories in this collection of Tanha Vagga verses includes mara shackles, fetters, arrows of life, trapped, treasures, and nets. Here are some examples of data analysis of expressions that represent the nine categories of objects used to create the metaphor of craving in Tanha Vagga.

People who worship craving

running around like a trapped rabbit, (TV342.a.)

bound in shackles, (TV 342.b.)

they experience repeated suffering

for a long time

The essence of the word trapped means being hit by a trap, while the meaning of trap according to the dictionary is a tool to catch animals using bait. This verse is based on the story of a woman who was reborn multiple times in the form of an animal. After having had the opportunity to listen to the Dhamma, she was finally able to realise her mistake and began to meditate on the object of the repulsive nature of the body, so she was reborn as a Brahma (Widjaya, 2013 p.802). It can be concluded from the background story that the low desires (craving) in a person's past life are a trap for that person to enter into a miserable life.

Judging from the criteria of the figurative trap symbol in the metaphorical expression (TV342.a.) it has conformity with the object category criteria. This shows that there is a form of human interaction with objects, which concrete examples include all minerals with predications that can break and can be 
destroyed. Thus, the creation of a metaphorical expression of craving for data (342.a.) with the figurative symbol of a trap can be classified as an object category in Haley's model of human perception.

The fragment of the verse that is included in the next object category is "bound by shackles" (TV 342.b.). In the Indonesian dictionary (KBBI, 2008: 163) shackles mean a tool to tie the feet or hands. Referring to the same background story as the data (TV 342.a.) the word shackles can be interpreted as the state of mind that was overwhelmed by many cravings/desires in the past life that will still bind (shackle) a person in the next birth.

Based on the criteria of the figurative symbol, the shackles in the metaphorical expression (TV342.b.) have conformity with the criteria for the object category. This shows that there is a form of human interaction with objects, which includes concrete examples of all minerals with predications that can break or be destroyed. Thus, the creation of a metaphorical expression of craving for data (342.b.) with figurative symbols of shackles can also be classified into the object category in Haley's model of human perception.

Another example of analysis of the use of the metaphor of craving in the Tanha Vagga of the Dhammapada scriptures in the object category is the following data quotation.

He who has attained the goal, fearless,

no craving, no stain.

He has destroyed the arrow of life.

This is his last life. (TV 351)

The phrase arrow of life comes from the words arrow and life. The arrow means a weapon in the form of a small stick, pointed, long, hairy at the base, and sharp at the end, released with a bow (KBBI, 2008). This verse has a background story of Rahula, the son of Gautama Buddha who was forced to sleep outside the monastery due to a large group of monks visiting the Jetavana monastery. Seeing this, Mara transformed into a very large elephant to frighten him. But it turned out that Rahula was not at all afraid. Gautama Buddha said that Rahula was an arahant and would not fear anything in this world. Knowing this, Mara left (Widjaya, 2013 p.832). The arrow of life here is a signifier of fear and the stain (defilement) which is a series of cravings or tanha (signified).

Judging from the figurative criteria for the arrow of life in metaphorical expressions (TV 351), it is following the criteria for the object category. This shows that there is a form of human interaction with objects that includes concrete examples of all minerals with predication that can be broken, damaged, and so on. Thus, the creation of Gautama Buddha's metaphorical expression with the figurative symbol of the arrow of life can be classified in the object category in Haley's hierarchy of human perception space.

Living

Here are some examples of data analysis of expressions that represent the seven categories of living that are used to create the metaphor of craving in Tanha Vagga.

The man whose life is negligent,

his craving grows like a creeping plant, (334.a.)

it floats from one realm to another,

like a monkey in the forest who longs for fruits. (TV 334.b.).

The essence of the word creeper can be found in the Indonesian dictionary (KBBI, 2008) as another word for vines, which is growing plants with long stems such as rattan. Thus the concept of creeping plants can be regarded as a concept of predication which is usually applied to plants such as rattan and sweet potatoes. In the metaphorical expression of the data (334.a.) the concept of creeping plants is regarded as a figurative symbol (signifier) of craving (signified).

Following the criteria of the figurative symbol of the creeping plant in the metaphorical expression (334.a.), it has conformity with the criteria of the living category. This shows that there is a form of human interaction with living, which includes concrete examples of all flora life with all its predication. 
Thus, the creation of a metaphorical expression of craving for data (334.a.) with the figurative symbol of a creeping plant can be classified in the living category in Haley's model of human perception.

Likewise, the fourth line in the verse reads "like a monkey in the forest who longs for fruits" (TV 334.b.). Monkey refers to the subject of the previous sentence, namely humans who are careless, while fruits are a signifier that refers to craving. Fruits can connote many desires (cravings).

Based on the criteria for the figurative symbol of fruit in the metaphorical expression (334.b.) it is under the criteria of the living category. This shows that there is a form of human interaction with living, which includes concrete examples of all flora life with all its predication. Thus, the creation of a metaphorical expression of craving for data (334.b.) with figurative symbols of fruit is also classified in the living category in Haley's model of human perception.

Likewise, the use of the metaphor of birana grass (TV data 337.a.), weeds (TV data 337.c.), tree (338 data), and shrubs (344.a. data) are a series of words in one semantic field that related to the life of flora, which acts as a signifier of craving (signified). These data all show that there is a form of human interaction with living, which includes concrete examples of all flora life with all its predication. Thus, the creation of the metaphorical expression of craving on the data is classified in the living category in Haley's model of human perception.

Animate

The predication for the animate category is the ability to walk, run or fly. The meaning field of animate human perceptual space is related to the world of fauna. Examples of nouns are limited to all kinds of fauna and their behavior. Phrases that use fauna metaphors in this collection of Tanha Vagga poems are not found, so there is no animate category used to create the metaphor of craving in Tanha Vagga.

Human

The human category is the field of meaning in the space of human perception related to the existence of humans themselves with all their behavior to meet their needs, including the ability to reason/think. Lexical expressions and phrases that are included in the human category are also expressions of anger, prostrating, fear, and smiling. There is also no data on this expression in the collection of Tanha Vagga verses, so there is no human category that is used to create the metaphor of craving in Tanha Vagga.

\section{Distribution Stage}

At the distribution stage, the researchers refer to Haley's opinion (Wahab, 2013), regarding hierarchical human perception. The concept is used to create a metaphor as a form of human interaction with the environment. In other words, the form of balanced distribution of usage for each category of Haley's perception space will include categories of being, cosmos, energy, substance, terrestrial, object, living, animate, and human. This was done to determine the distribution of Haley's model of spatial category distribution, which is the most prominent in the metaphorical expression of Tanha Vagga's verses. In addition, the results of the percentage distribution will reflect the state of the ecological system in Tanha Vagga verses. In the process of finding the percentage distribution of this stage, the researchers use the following formula:

$$
\begin{array}{ll}
\underline{\mathrm{X}} \times 100=\mathrm{P} & \text { Where } \\
\mathrm{Y} & \mathrm{X}=\text { Total frequency } \\
\mathrm{Y}=\text { Total data } \\
\mathrm{P}=\text { Percentage distribution result }
\end{array}
$$

Next, the presentation of data from the stage of finding the distribution of the percentage usage of Haley's model of human perceptual space category is shown in the following table. 
Table 1 Distribution of Haley's Model of Human Perceptual Space Category

\begin{tabular}{clll}
\hline No. & Category & Frequency & Percentage \\
\hline 1. & Being & 4 & $13 \%$ \\
\hline 2. & Cosmos & 0 & $0 \%$ \\
\hline 3. & Energy & 3 & $9,6 \%$ \\
\hline 4. & Substance & 0 & $0 \%$ \\
\hline 5. & Terrestrial & 4 & $13 \%$ \\
\hline 6. & Object & 9 & $29 \%$ \\
\hline 7. & Living & 11 & $35,4 \%$ \\
\hline 8. & Animate & 0 & $0 \%$ \\
\hline 9. & Human & 0 & $0 \%$ \\
\hline & Total & 31 & $100 \%$ \\
\hline
\end{tabular}

Based on the results of the distribution of the use of Haley's model of human perceptual space to create the metaphorical expression of craving in the Tanha Vagga of the Dhammapada scripture in table 1 , there are several interesting things to be explained. The first, in creating metaphorical expressions in the Tanha Vagga verses of the Dhammapada, Gautama Buddha mostly uses the living category with a percentage distribution of $35.4 \%$. The second is the object category with a percentage distribution of $29 \%$, and the third is and terrestrial category, which respectively has the same percentage distribution of $13 \%$. While the fourth, or last is the energy category with a percentage distribution of $9.6 \%$.

\section{The Unbalanced Ecological Metaphor of Tanha Vagga in Dhammapada}

Based on the analysis of 31 metaphorical expressions of lust in the Tanha Vagga scriptures of the Dhammapada, the researchers conclude three interesting findings to convey. Firstly, the researcher found only five categories of human perceptual space according to Haley's model in creating the metaphor of lust in the Tanha Vagga scripture of Dhammapada. The five categories are being, energy, terrestrial, object, and living. Secondly, based on the results of the distribution of the use of Haley's model human perceptual space, the researcher found the living category as the most prominent type of craving metaphor category with a percentage distribution of $35.4 \%$ (see table 4.2 ).

The distribution of the use of Haley's model of human perceptual space apart from the living category as the most prominent for creating the metaphorical expression of craving in the Tanha Vagga other categories showed as follow: the being category and the terrestrial category, each of which has a percentage which is $13 \%$, the third position is the object category $(29 \%)$, the fourth position is the energy category $(9.6 \%)$. Meanwhile, Haley's four other categories of human perceptual space, namely the cosmos category, substance category, animate category, and human category were not found to be used as metaphors for craving in the Tanha Vagga scripture Dhammapada.

Thirdly, the researcher found a state of unbalanced ecological system in the Tanha Vagga scripture Dhammapada. The results of the percentage distribution presented show that the form of Gautama Buddha's interaction with his environment is not balanced (the state of the ecological system is not balanced). The existence of an imbalance in the interaction of Gautama Buddha with his environment is implied from the unbalanced distribution of the use of Haley's model of human perception categories. This is evidenced by the distribution of the use of one of the most prominent categories used by Gautama Buddha in creating the metaphor of craving in the Tanha Vagga of the Dhammapada scriptures, which is seen in the living category, while no other four categories are found, namely the cosmos category, the substance category, the animate category, and the human category. Thus, there is an imbalance in the distribution of the use of Haley's model of human perceptual space categories in creating poet metaphors, so the state of the ecological system in the Tanha Vagga verses of the Dhammapada can be declared unbalanced.

The analysis of this study confirms the theory of metaphor associated with the study of ecological systems (Haley's model of human perceptual space). This is evidenced by the findings of the use of five 
out of nine categories of Haley's model of human perceptual space in creating the metaphorical expression of craving in the Tanha Vagga scripture Dhammapada.

\section{Conclusions}

Based on the results of data analysis and discussion in this study, it can be concluded as follows: Haley's model of human perceptual space used to create the metaphor of craving in the Tanha Vagga verse of the Dhammapada Scripture consists of five categories, namely, a) being category, b) energy category, c) terrestrial category, d) object category, and e) living category.

The distribution of the use of Haley's model of human perceptual space category used to create the metaphor of craving in the Tanha Vagga of the Dhammapada scriptures shows that there is an unbalanced state of the ecological system. This is evidenced by the uneven distribution of the use of each category of Haley's model of human perceptual space in creating poet metaphors. The imbalance in the distribution is shown by the distribution of the most prominent living category with the distribution of the percentage being $35.4 \%$, while the other four categories are even only $0 \%$. In addition, Gautama Buddha's interaction with the thinking environment creates a closer metaphor for the living category (all kinds of flora-related life). The metaphorical expression of craving in the Tanha Vagga of the Dhammapada scriptures is packaged in a metaphorical form which has the meaning of controlling craving (desire, inclination) of a strong heart or tanh $\bar{a}$ (Pali) which is the cause of $d u k k h a$ (suffering) and the cycle of rebirth (samsāra). Buddhism seeks to eliminate tanh $\bar{a}$ by inviting its adherents to follow the Great Eightfold Path to eliminate dukkha. The strategy for expressing these values is in the form of metaphorical expressions based on the Haley model of human perceptual space. This finding also indicates that metaphors are not merely in the words we use but are more since human thought processes and some of their systems of understanding are metaphorical.

\section{References}

Assarroudi, A., Heshmati Nabavi, F., Armat, M. R., Ebadi, A., \& Vaismoradi, M. (2018). Directed qualitative content analysis: the description and elaboration of its underpinning methods and data analysis process. Journal of Research in Nursing, 23(1), 42-55. https://doi.org/10.1177/1744987117741667

Croft, W., \& Alan Cruse, D. (2004). Cognitive Linguistics. Cambridge: Cambridge University Press.

Departemen Pendidikan Nasional. (2008). Kamus besar bahasa Indonesia (empat). Jakarta: PT Gramedia Pustaka Utama.

Ganiwati, W. S. (2020). Metafora Dalam Novel Laskar Pelangi Karya Andrea Hirata (Analisis Stilistika). Jurnal Salaka: Jurnal Bahasa, Sastra Dan Budaya Indonesia, 2(2), 111-120.

Hendriyani, H. (2017). Analisis Isi: Sebuah Pengantar Metodologi yang Mendalam dan Kaya dengan Contoh. Jurnal Komunikasi Indonesia, 2(1), 63-65. https://doi.org/10.7454/jki.v2i1.7832

Keraf, G. (2010). Diksi dan Gaya Bahasa. Jakarta: Gramedia Pustaka Utama.

Kridalaksana, H. (1993). Kamus Linguistik. Jakarta: Gramedia Pustaka.

Kroppendorf, K. (1980). Analisis Isi: Pengantar Teori dan Metodologi (Alih Bahasa Farid Wajidi). Jakarta: PT. Rajagrafindo.

Mahsun, M. S. (2011). Metode Penelitian Bahasa: Tahapan Strategi, Metode, dan Tekniknya. Jakarta: PT Raja Grafindo Persada.

Monggilo, Z. M. Z. (2020). Analisis Konten Kualitatif Hoaks Dan Literasi Digital Dalam @Komikfunday. Interaksi: Jurnal Ilmu Komunikasi, 9(1), 1-18. https://doi.org/10.14710/interaksi.9.1.1-18

Nabila, U., \& Hasanah, M. (2021). Metafora dalam Kumpulan Puisi Sajak-Sajak Lengkap 1961 - 2001 Karya Goenawan Mohamad. BASINDO: Jurnal Kajian Bahasa, Sastra Indonesia, Dan Pembelajarannya, 5(2), $239-249$.

Nugrahani, F. (2014). Metode Penelitian Kualitatif dalam Penelitian Pendidikan Bahasa. Surakarta: Deepublish.

Oktavia, W. (2019). Metaphor and Interpretation of Social Criticism of Community in Iwan Fals Albums. Jurnal KATA, 3(1), 15-22. https://doi.org/10.22216/kata.v3i1.3882

Pebriawati, T. W. (2016). Metafora Cinta Dalam Risalah "Tauq Al-Hamamah" Karya Ibn Hazm Al-Andalusiy (Analisis Semantik). UIN Sunan Kalijaga Yogyakarta.

Subandi. (2011). Qualitative Description as one Method in Performing Arts Study. Harmonia, 11(2), $173-179$.

Suriyadi, S. (2013). Ungkapan-Ungkapan Metaforis Dalam Puisi-Puisikarya Agus R. Sardjono. Litera, 12(2), 312327. https://doi.org/10.21831/ltr.v12i02.1591 
Wahab, A. (2013). Metafora Sebagai Pelacak Sistem Ekologi. Jakarta: Kanisius.

Widjaya, H. (2013). Dhammapada (Syair Kebenaran). Jakarta: Ehipasiko.

Yuniseffendri, Y. (2014). Revitalisasi 'Alam Terkembang Jadi Guru' Dalam Budaya Berbahasa di Minangkabau: Analisis Pemanfaatan Simbol Metafora dalam Pepatah-Petitih Minangkabau. Paramasastra, 1(2), 1-14. https://doi.org/10.26740/parama.v1i2.1478 and conditions of the Creative Commons Attribution (CC BY SA) license (https://creativecommons.org/licenses/by-sa/3.0/). 